\title{
From the First Nuclear Explosion up to the Signing of Non-Proliferation Treaty of Nuclear Weapons
}

\author{
Mentor Lecaj \\ PhD student in the field of International Law, \\ Lecturer in subjects "International Law" and "European Law", \\ Faculty of Public Administration - AAB College, Pristine
}

Doi:10.5901/ajis.2016.v5n3s1p331

\begin{abstract}
Since the beginning of this nuclear era, one part of the international pacific community continually had tried, to reduce the risks posed by the existence of nuclear weapons proliferation. The environmental risks from explosions of nuclear tests in the atmosphere had increased the danger as a result of the competition of nuclear weapons triggered various initiatives from the very early design for international legal norms aiming to limit nuclear testing. This work paper tries to, describe, discuss and analyze historical data on political spirit before signing the NPT. More over this article considers and trying to give interpretations to the official political statements and declarations on unpredictable issue for the future, which it might have serious consequences for international security. The findings in this article are that competition of nations in having nukes and increasing their numbers and capabilities are one the main part in chain reaction factor that can bring proliferation in high alert and humankind in greater risk situation
\end{abstract}

Keyword: Historical data, NPT, Peaceful use, Noncompliance activities, Security

\section{Introduction}

This article provides historical data on effort taken by main international stakeholders aiming to reduce the risk from nuclear nonproliferation.

As a paper work which aims to give an outlook on genesis of nuclear weapon and official statements from most important official person at that time can be feel the spirit of danger exist and can be occurred in future.

Importance of this work is related very closely in raising the awareness of humankind in era we are living.

\section{From the First Nuclear Explosion up to the Signing of Non-Proliferation Treaty of Nuclear Weapons}

United States were the first state to test and opened the doors for Weapons of Mass Destruction (henceforth -WMD). ${ }^{1}$ The Manhattan Project, it was he who brought the production of nuclear weapons, and which had been used on two Japanese cities, Hiroshima and Nagasaki. These bombings on the one hand helped in ending World War II, while on the other side opened the beginning of a new era in the field of international law and international relations, regarding global security. ${ }^{2}$ The USSR (Soviet Union) in trying to balance US in opposing in every field of social life (political, economic, military), successfully tested in 1949 its first nuclear weapon. ${ }^{3}$ The rivalry contest between the main winning countries of

\footnotetext{
1 It is very interesting to be emphasized that Germans were the first who planned an atomic bomb. Today are some written books, example by historian Rainer Karlsch who states that Germans were the first who tested the three test of atomic bomb, 1944-45. But this theory is not profaning yet. But what is proved is that Germans were the fist who planned to get an atomic bomb. For more visit the Klaus Wiegrefe, The Third Reich: How close was the Hitler to A-Bomb? Spiegel online international, Ausgabe 11, 2005, http://www.spiegel.de/international/spiegel/the-third-reich-how-close-was-hitler-to-the-a-bomb-a-346293.html, visited on 19.08.2016. $14: 49$.

${ }^{2}$ The Baruch Plan, The United States Presents Baruch Plan, June 14, 1946, accessed at http://www.history.com/this-day-in-history/theunited-states-presents-the-baruch-plan, visited at 18.11..2016, 10;45.

3 The race between two superpowers will start during World War II. In both side when we analyses the evidences from today perspective we conclude that they were in panic that is going to dominate whom. The American intelligence were convinced and assumed in August 1946, suggesting that Moscow could produce an atomic device between 1950-1953. But in 1948, they estimated an early date 
World War II will not end with that, and nuclear proliferation will continue further, followed by the United Kingdom in October 1952, ${ }^{4}$ France, ${ }^{5}$ and Communist China. ${ }^{6}$ Also India ${ }^{7}$ and Pakistan ${ }^{8}$ demonstrated their internal nuclear capabilities, although these were not considered applicable to full nuclear rights, while they tested their nuclear weapons ambitions in $1998 .{ }^{\circ}$ Canadian scholar Ashok Kapur after the India test predicted that trend of proliferation would be increased. He suggested that weaponized would be countries as follow: Israel, Japan, Australia, South Africa, Brazil, South Korea, Taiwan, and Argentina as countries widely perceived as potential nuclear states. ${ }^{10}$

However, although it remains far unverified, it is assumed that only Israel since 1950 covertly was able

forecasting that Russian can produce a bomb in middle of 50s, although the most probable date was still predicted to be mid-1953. The estimate has been made just five day in an August 1949 report disseminated five days before the actual Soviet atomic test. Following the test, American forecasts about the Soviet Union transitioned into examinations of the relative strengths of the two sides. Forecasts regarding the nuclear capability of the two superpowers saw a progressive shift of balance in Moscow's favor. After the test regarding the nuclear capability of the two superpowers had been made a progressive shift of balance in Moscow's favor. Some prediction in 1950s, were very shocking for US administration, were some related projections pointed to the probable accelerated modernization of the Soviet nuclear arsenal in an attempt to gain parity with the United States. However, in the early-to-mid 1960s, after the Berlin and Cuban missile crises, U.S. intelligence assumed that the Moscow would abandon its motivation and ambition to gain a substantial advantage over Washington. But another estimation in the late 1960s, and by the year of 1969 National Intelligence Estimate (NIE) stating that the USSR would seek "parity with the U.S.". This would be reached by soviets not only by incising number of atomic bombs but as well they will be focused on qualitative comparison with American nuclear forces. During the late-1980s, when economic frailties and internal political turmoil had made any talk of Soviet military supremacy redundant, the CIA's view prevailed in most forecasts. For more visit at Moeed Yusuf, Predicting Proliferation: The History of the Future of Nuclear Weapons, Policy Paper, Number 21, Boston University, January 2009. p. 8-9.

${ }^{4}$ British also had developed its own atom bomb to remain a great power and to be independent from United States... After secret meeting committee discussed the question in October 1946, By the time the bomb was ready for testing, the Churchill government was in power. The scientific director was to be Dr. W.G. Penney, the ministry's chief superintendent of armament research, a nuclear physicist who had worked on the world's first atomic bomb in America. A combined British and Australian naval force of aircraft carriers, a destroyer, frigates and tank landing ships was assembled for the operation. The bomb was put in an anchored frigate, HMS Pym, and when it exploded at 8am local time on October 3rd thousands of tons of rock, mud and sea-water were blasted into the air. 'For more visit, Richard Cavendish, Published in History Today Volume 52 Issue 10 October 2002, http://www.historytoday.com/richardcavendish/first-british-atomic-bomb-test, visited on 20.07.2016.18;20.

${ }^{5}$ On 13 February 1960, France conducted its first nuclear test, code-named "Gerboise Bleue" (Blue Desert Rat). This atomic bomb comparing with Hiroshima's bomb around four times more powerful. Subsequent French nuclear testing was conducted at French Polynesian atolls in the South Pacific, site of atmospheric thermonuclear tests, starting with the 2.6 megaton Canopus test in August 1968. For more visit at https://www.ctbto.org/specials/testing-times/13-february-1960-the-first-french-nuclear-test, 20? 07/2016, 18:26.

${ }^{6}$ The People's Republic of China joins the rank of nations with atomic bomb capability, after a successful nuclear test on this day in 1964. China became the fifth member which is coincidence with permanent member of Security Council at the United Nations. The attention to get a nuke in her hands China started at early at 50s For that the U.S. officials were not terribly surprised by the test The Russian experts had helped the China to get the $A$ bomb , who later after the split would be very concern of it regarding the ideological and strategic issues. This test increased the tensions between the two nations. For more visit on http://www.history.com/this-day-inhistory/china-joins-a-bomb-club, 20.07.2016, 18:32.

7 India as well conducted its first nuclear detonation, called by India as a "peaceful nuclear explosion," on 18 May 1974. This test was partially successful. It is reported that the American intelligence community estimated that the actual yield was in the range of 4 to 6 kilotons. High-resolution commercial satellite imagery. Calculated that the radius of substantial area was about 60 meters, and is surrounded by a distinctive perimeter with a radius of roughly 80 meters. For more visit at, FAS (Federation of American Scientists), http://fas.org/nuke/guide/india/nuke/first-pix.htm, visited on 20.07.2016, 18:09.

${ }^{8}$ On May 28, 1998, Pakistan stated that it had successfully committed five nuclear tests. This statement also is proven by The Pakistani Atomic Energy Commission who reported that the five nuclear tests conducted which generated a seismic signal of 5.0 on the Richter scale, with a total yield of up to 40 KT (equivalent TNT). On May 30, 1998 Pakistan tested again another nuclear warhead. The tests were conducted at Baluchistan, bringing the total number of claimed tests to six. For more visit on, A Brief History of Pakistan's Nuclear Program, for more visit on FAS (Federation of American Scientists), A Brief History of Pakistan's Nuclear Program, http://fas.org/nuke/guide/pakistan/nuke/, visited on 20/07/2016, 18:44.

9 India-Pakistan: Nuclear Weapon Update, The Risk Report, Volume 4 Number 6 (November-December 1998), accessed at http://www. wisconsinproject.org/countries/pakistan/nuke98.html, visited at 08.11.2016.

10 Yusuf, Moeed, Predicting Proliferation: The History of the Future of Nuclear Weapons, Policy Paper, Number 21, Fellow, Frederick S. Pardee Center for the Study of the Longer-Range Future, Boston University, January 2009, p. 21. 
successfully possess nuclear capability. ${ }^{11}$

Since the beginning of this nuclear era, the international community continually had tried, to reduce the risks posed by the existence of nuclear weapons proliferation. Furthermore the environmental risks from explosions of nuclear tests in the atmosphere had increased the danger as a result of the competition of nuclear weapons, has triggered various initiatives from the very early design for international legal norms aiming to limit nuclear testing. ${ }^{12}$

In the framework of this initiative we can distinguish a statement of British Prime Minister Winston Churchill, were according to him, the "Peace is the sturdy child of terror. For me, such a peace is a wretched offspring, a peace that condemns us to live under a dark cloud of perpetual anxiety, a peace that codifies mankind's most murderous instincts. . . The beast (nuclear weapons) must be chained, its soul expunged, its lair laid waste." ${ }^{13}$ Contrary to this initiative idea it exist group of thinkers who deal with this issue and believed and still believe today on the deterrence of states by the using of these weapons. They usually assume that such weapons can be controlled by a small number of major responsibility powers. Therefore, this theory presupposes the nuclear monopoly, which underscores the logic of the early non-proliferation, given the permanent members of the Security Council of the UN Security Council (the more powerful chamber of the international community). ${ }^{14}$ One of the significant effort for nuclear non-proliferation, after the World War II can be considered that beginning of the adoption of the so called Baruch Plan of Truman Administration, where Acheson-Lilienthal's report(1946) proposed to verify disarmament and eventual destruction of U.S nuclear arsenals (the only nuclear arsenal at that time). Truman's administration felt and believed so "naive" that doing so would reduce international tensions in the future and eliminating the arms race in this area. ${ }^{15}$

Unilateral disarmament of US never happened, and finally Baruch Plan was abandoned after the Soviet Union soon produced its own WMD. When US President Eisenhower took office, he laid out a program called "Atom for Peace" (1953), which will bring a sort of degree to international transparency in nuclear technology race and who will lead to a general system of safeguards nonproliferation nuclear weapons. ${ }^{16}$ The "Atom for Peace" was followed by the establishment of the International Atomic Energy Agency (IAEA 1957), which at the beginning was not so serious effort until 1960, in reaching an international agreement on limiting nuclear proliferation. Until the above mentioned process the USSR, France and Great Britain have reached their possession of nuclear weapons. The Eisenhower said the international community had to wait eight years with the threat of spreading tension, while nuclear armed states agreed to halt the spread. ${ }^{17}$

By analyzing also a statement of US President John F. Kennedy, delivered at a press conference, on 23 March 1963 before signing the NPT, which described a world where up to 1970 may own more than 10, 15 or more than 25 nuclear weapons countries, then there is a "greater potential risk and a game of chance with life on earth." From this declaration can be concluded that at that time he saw more potential that could soon spread the nuclear weapons. Therefore the beginning of the 1960s, efforts to reach a legally binding agreement to prevent the further spread of nuclear weapons, began to intensify, and showing the results. Even the United Nations General Assembly, in 1961, adopted a resolution sponsored by Ireland urging all states to reach an agreement that would ban the purchase and transfer of nuclear weapons further. As well as in 1965, the Geneva Conference on Disarmament began in drafting the treaty on nuclear nonproliferation. ${ }^{18}$ This consensus between states were regulated and sanctioned by the Non-Proliferation Treaty (NPT), which entered into force in March 1970. Scientists like Richard Kokoski, research SIPRI (Stockholm International Peace Research Institute) for military technology and project control of the weapons, argued that the NPT has

\footnotetext{
${ }^{11}$ Borger Julian, The truth about Israel's secret nuclear arsenal, The Guardian, Wednesday 15 January 2014 18.18 GMT, accessed at, https://www.theguardian.com/world/2014/jan/15/truth-israels-secret-nuclear-arsenal, visited at 08.11.2016.

12 Committee on technical issues related to ratification of the comprehensive test ban treaty -Technical issues related to the comprehensive nuclear test ban treaty, National Academy Press Washington, D.C., 2002, preface, p vii.

$13 \mathrm{http}: / /$ midtermpapers.com/essays/peace-is-the-sturdy-child-of-terror-for-me-such-a-peace-is-a-wretched-offspring-a, visited on 20.07.2016, 23:55.

14 The Baruch Plan, the US Presented Baruch Plan. June 14, 1946, accessed at http://www.history.com/this-day-in-history/the-unitedstates-presents-the-baruch-plan, visited on 08.11.2016.

15 The Acheson-Lilienthal \& Baruch Plans, 1946, accessed at https://history.state.gov/milestones/1945-1952/baruch-plans visited at 18.11.2016, 11:13.

16 Etemikef, Laz, The Politics of nuclear non-Proliferation, Cejiss 3-4/2012, p. 15.

17 Ibid, p. 15-16.

18 US delegation to the 2010 Nuclear Nonproliferation Treaty Review Conference, 2010 NTP, Treaty of the Non-proliferation of Nuclear Weapons, accessible on Google free access.
} 
established a sufficient legal framework to control the spread of nuclear materials and expertise. More than that, the signatories of this Treaty, vowed not to take any action that would increase the number of countries with nuclear weapons. ${ }^{19} \mathrm{~A}$ signatory of the treaty are 190 member states, including five countries with nuclear weapons. ${ }^{20}$ Many countries have also ratified. Israel, India and Pakistan have never been a signatory of the Treaty. North Korea, which had acceded to the Treaty in 1985, withdrew from it in 2003. ${ }^{21}$

Treaty without any changes so far assumes that states that do not possess nuclear weapons, and which are parties to the treaty must not produce or purchase nuclear weapons or other explosive nuclear devices. But for the existing nuclear-armed states, the treaty does not require and does not oblige to submit their nuclear weapons, but recommends them to negotiate between them in good faith to eliminate such weapons. For non-nuclear weapon states (NNWS Non-Nuclear Weapon State) there is no room for negotiation. Consequently, the treaty has created two classes or groups of countries, such as: countries with nuclear weapons and country without nuclear weapons. ${ }^{22}$

It should be emphasized that as a case today DPRK (North Korea Nuclear Program) and Iran belongs to the second group of states without nuclear weapons. The research question can be arisen in giving clear answer the legal framework of international nuclear security in preventing the spread of nuclear weapons in the North Korea, whether is sufficient or it is a necessary an additional deal creating a free zone of nuclear weapons?

The answer it is that a best solution at the moment for all humanity it can be if the negotiations would come to an end by signing the agreement which would establish a Nuclear Free Zone without Nuclear Weapon.

\section{Conclusion}

Scientific thoughts on the meaning and definition of the concept of international security, particularly in nuclear security cannot be understand without elaborating in detail the genesis and effort of many stakeholders toward signing the NPT.

Elaboration of the genesis efforts above, it is important for the international legal framework on nuclear safety, because the regulation of the relations in this issue, between the parties and international actors (states, organizations and international agencies and different groups of interest) cannot be understood fully unless can be understood the history of nuclear international security in general. Also the completion of this framework in the sphere of nuclear security as a part of historic deal it is very gapufully understand unless analyzing the actions of stakeholders toward reducing the nukes and signing the NPT.

Whatever the concern, the global security is becoming day by day current topic, pushed by the different modalities of the threats to all of human values and the necessity of their protection.

\section{References}

Borger Julian, The truth about Israel's secret nuclear arsenal, The Guardian, Wednesday 15 January 2014 18.18 GMT, accessed at, https://www.theguardian.com/world/2014/jan/15/truth-israels-secret-nuclear-arsenal.

Committee on technical issues related to ratification of the comprehensive test ban treaty -Technical issues related to the comprehensive nuclear test ban treaty, National Academy Press Washington, D.C., 2002.

Etemikef Laz, The Politics of nuclear non-Proliferation, Cejiss 3-4/2012.

FAS (Federation of American Scientists), A Brief History of Pakistan's Nuclear Program, http://fas.org/nuke/guide/pakistan/nuke.

http://midtermpapers.com/essays/peace-is-the-sturdy-child-of-terror-for-me-such-a-peace-is-a-wretched-offspring-a.

https://www.ctbto.org/specials/testing-times/13-february-1960-the-first-french-nuclear-test,

http://www.history.com/this-day-in-history/china-joins-a-bomb-club.

India-Pakistan: Nuclear Weapon Update, The Risk Report, Volume 4 Number 6 (November-December 1998), accessed at http://www.wisconsinproject.org/countries/pakistan/nuke98.html,

Klaus Wiegrefe, The Third Reich: How close was the Hitler to A-Bomb? Spiegel online international, Ausgabe 11, 2005,

\footnotetext{
${ }^{19}$ Etemikef, Laz, The Politics of nuclear non-Proliferation, Cejiss 3-4/2012, p. 16.

20 NPT defines a nuclear weapons state, the state, which has manufactured and exploded a nuclear weapon-test or other nuclear device before 1 January 1967. These countries are: China, France, Russia, UK and USA. All other states are states with non-nuclear weapons under the Treaty.

${ }^{21}$ Miller, Marvin and Scheinman, Lawrence, Israel, India, and Pakistan: Engaging the Non-NPT States in the Nonproliferation Regime, Arms Control Association, December 1, 2003, accessed at https://www.armscontrol.org/act/2003_12/MillerandScheinman, visited at 08.11.2016.14:35.

${ }^{22}$ Etemikef Laz, The Politics of nuclear non-Proliferation, Cejiss 3-4/2012, p.16.
} 
http://www.spiegel.de/international/spiegel/the-third-reich-how-close-was-hitler-to-the-a-bomb-a-346293.html,

Miller, Marvin and Scheinman, Lawrence, Israel, India, and Pakistan: Engaging the Non-NPT States in the Nonproliferation Regime, Arms Control Association, December 1, 2003, accessed at https://www.armscontrol.org/act/2003_12/MillerandScheinman.

Moeed Yusuf, Predicting Proliferation: The History of the Future of Nuclear Weapons, Policy Paper, Number 21, Boston University, January 2009

Richard Cavendish Published in History Today Volume 52 Issue 10 October 2002, http://www.historytoday.com/richard-cavendish/firstbritish-atomic-bomb-test.

The Acheson-Lilienthal \& Baruch Plans, 1946.

The Baruch Plan, The US Presented Baruch Plan. June 14, 1946, accessed at http://www.history.com/this-day-in-history/the-unitedstates-presents-the-baruch-plan.

US delegation to the 2010 Nuclear Nonproliferation Treaty Review Conference, 2010 NTP, Treaty of the Non-proliferation of Nuclear Weapons, accessible on Google free access.

Yusuf, Moeed, Predicting Proliferation: The History of the Future of Nuclear Weapons, Policy Paper, Number 21, Fellow, Frederick S. Pardee Center for the Study of the Longer-Range Future, Boston University, January 2009. 